Historic, Archive Document

Do not assume content reflects current scientific knowledge, policies, or practices. 



\title{
Wonderful Orchard Bargains for April Planting
}

\author{
April is the Biggest and Best Planting Month of \\ the Year. Grasp These Unequalled Opportuni- \\ ties to Get Your Trees at a Saving of 50 to $75 \%$.
}

$\mathrm{N}^{\mathrm{B}}$

EVER before have you had a chance to get high quality trees and plants at such a remarkable saving. These values are made possible only by our plan of cutting out the old round-about way of doing business-the four profit plan-saving you jobber's, dealer's and agent's expenses aud profits. Planters Trees are sold by the million straight to the farmer and fruit-grower.

You not only save all these commissions and expenses, and the cost of printing and mailing big costly catalogs, but guaranteed stock fresh from the nursery-sturdy, healthy, big rooted trees that will grow and bear true to name. The Planters plan not only lowers the price, but it raises the quality. Compare the stock we send you with trees that have cost you two to four times as much. If Planters stock isn't as good as you think it ought to be, it won't cost you a cent. Our big, broad guarantee makes you the judge-brings your money back if you are not compietely satisfied.

You have plenty of time yet, if you set Planters trees. We ship and guarantee trees to reach you in good plant- ing condition until the last of May. No matter how far your season is advanced-even if trees are in full leafyou can safely plant our trees. We insure them to reach you in the right condition to grow.

But April is the big planting month. The earlier you plant the better, so make out your order and mail it today. Remember the Planters Guarantee. You take no risk whatever. If you're not more than satisfied with the trees we send you-if they don't arrive in first-class condition, we will refund every cent including transportation charges.

\section{Selections Made Especially for Your Locality}

\section{Let Us Pick the Best Varieties for You}

1 know a fourteen year old orchard of 2800 apple trees that would make five times as much money for the owner if he had only selected right varieties. Thousands of orchards are yielding no profit or have proved total failures because wrong varieties were planted. If you're not sure what's best for your locality, let us help you. In the following offers, we'll select the kinds that you can depend on-the tried and proven sorts for your section. You'll be sure of getting varieties that will grow and bear good crops of fruit every favorable year. There's no charge for this service-you get the same low prices as on our other collections. In ordering these assortments, tell us whether you wish early, medium, or late varieties; also whether you're planting a home orchard or for market.

No. 101-20 Apple Trees, $2 \cdot 3 \mathrm{ft}, 1 \mathrm{yr}$

102-10 Apple Trees, 3-5 ft, 1 yr $\ldots \ldots . . . .95$

103-20 Apple Trees, $3-5 \mathrm{ft}, 1 \mathrm{yr}$

104-50 Apple Trees, $3-5 \mathrm{ft}, 1 \mathrm{yr}$

105-10 Apple Trees, $4-5 \mathrm{ft}, 2$ yr

106-20 Apple Trees, $4-5 \mathrm{ft}, 2$ yr _...... 1.85

107-50 Apple Trees, $4-5 \mathrm{ft}, 2$ yr

108-10 Apple Trees, 5-6 ft, 2 yr _..._.. 1.25

109-20 Apple Trees, 5-6 ft, 2 yr _-..-- 2.40

110-50 Apple Trees, $5-6 \mathrm{ft}, 2$ yr ..... 5.50

111-10 Peach Trees, 2-4 ft ._-_._._. . .85

112-20 Peach Trees, $2-4 \mathrm{ft}$

113-50 Peach Trees, 2-4 ft ........... 3.50

114-10 Peach Trees, $4-6 \mathrm{ft}$...._._..... 1.40

115-20 Peach Trees, $4.6 \mathrm{ft}$

116-50 Peach Trees, $4-6 \mathrm{ft}$

117- 5 Plum Trees, $2-4 \mathrm{ft}$

118-10 Plum Trees, 2-4 ft......... 1.40

119-20 Plum Trees, 2-4 ft

120- 5 Plum Trees, $4-6 \mathrm{ft}_{\text {-...-.... }} 1.00$

121-10 Plum Trees, 4-6 ft

122-20 Plum Trees, $4-6 \mathrm{ft}$

123-10 Pear Trees, $2-4 \mathrm{ft}, 1 \mathrm{yr} . \ldots-. .80$

124-20 Pear Trees, $2.4 \mathrm{ft}, 1 \mathrm{yr}$....... 1.55

125-50 Pear Trees, 2-4 ft, 1 yr..... 3.50

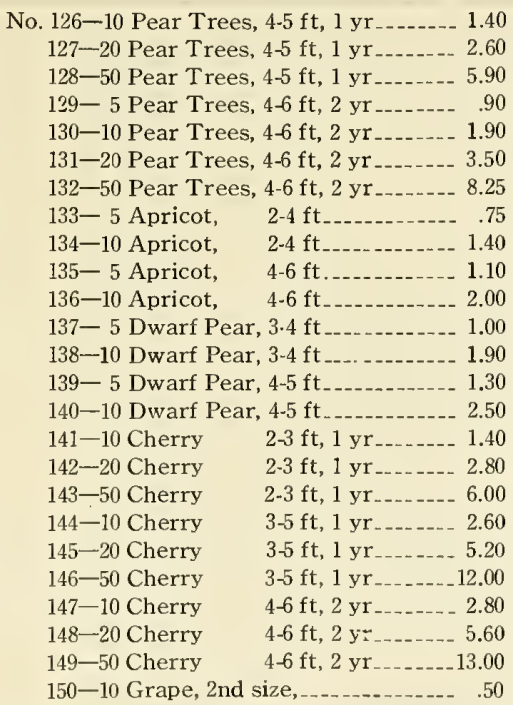

o. 126-10 Pear Trees, $4-5 \mathrm{ft}$, $1 \mathrm{yr}$

127-20 Pear Trees, $4-5 \mathrm{ft}, 1 \mathrm{yr}$

$129-5$ Pear Trees, $4-6 \mathrm{ft}, 2 \mathrm{yr}$

130-10 Pear Trees, $4-6 \mathrm{ft}, 2 \mathrm{yr}-1.90$

131-20 Pear Trees, $4-6 \mathrm{ft}, 2 \mathrm{yr}$

-50 Pear Trees, 4-6 ft, 2 yr_._._.-- 8.25

134-10 Apricot, $\quad 2-4 \mathrm{ft}$

135- 5 Apricot, $4-6 \mathrm{ft} \ldots-1.10$

136-10 Apricot, $\quad 4-6 \mathrm{ft}-2.00$

338-10 Dwarf Pear, 3-4 ft

139- 5 Dwarf Pear, 4-5 ft $-1,30$

Dwarf Pear, $4-5 \mathrm{ft}$

$142-20$ Cherry $2-3 \mathrm{ft}, 1 \mathrm{yr} \ldots$

$2-3 \mathrm{ft}, 1 \mathrm{yr}-6.00$

$3-5 \mathrm{ft}, 1 \mathrm{yr}-2.60$

$35 \mathrm{ft}, 1 \mathrm{yr}---1200$

$4-6 \mathrm{ft}, 2 \mathrm{y}=-5.60$

150-10 Grape, 2nd size, ....... .50
No.151- 25 Grape, 2nd size,

152-100 Grape, 2nd size,

153-500 Grape, 2nd size, _. 9.50

154- 10 Grape, lst size,

155- 25 Grape, 1st size, 1.50

156-100 Grape, 1st size, ._._._____. 4.20

157-500 Grape, 1st size,

158- 25 Blackberry, 1st size _-_-_. .75

159-100 Blackberry, 1st size _..._-_-_.- 2.40

160-500 Blackberry, 1st size _-_____ 8.75

161- 25 Blackberry, 2nd size -50

162-100 Blackberry, 2nd size _......-. 1.65

163-500 Blackberry, 2nd size

164- 25 Raspberry, No. 1,_-______. .50

165-100 Raspberry, No. 1,_____ 1.80

166-500 Raspberry, No $1,-7.00$

167- 10 Gooseberry, No. 1,_......... . .95

168- 25 Gooseberry, No. $1,-1.50$

169-100 Gooseberry, No. 1,_ 4.50

$170-25$ Strawberry, strong plants

$171-100$ Strawberry, strong plants $\ldots .75$

172-500 Strawberry, strong plants_.. 2.50

173- 10 Hardy Flowering Shrubs .... 1.50

174- 5 Hardy Roses, 2 yr._.__ 1.40

175- 25 Dewberry, strong plants_.... .45
No. 1-Apple collection. 10 select 5 to $6 \mathrm{ft}$. trees: 1 Delicious, 2 Stayman, 1 Black Ben, 2 M. B. Twig, 1 Grimes Golden, 3 Winesap. \$1.50 Sold by agents for $\$ 5.00$

No. 6-20 Peach Trees. 4 to $5 \mathrm{ft}$. Elberta, Champion, Mamie Ross, Belle of Georgia, the cream of good varieties.

Agents charge $\$ 5.00$

No. 8-5 Apricot Trees. 4 to $5 \mathrm{ft}$. Moorpark and Superb, hardiest and best quality. Agents get $\$ 6.00$

No. 11-10 Plum Trees. 3 to $5 \mathrm{ft}$. Burbank, Abundance, Satsuma and Wickson, quick bearers. Agents charge $\$ 4.00$
$\$ 1.10$

$\$ 1.50$
No. 14-Grape Collection. 10 Choice 2 year vines, 1 Catawba, red; 3 Concord, black; 2 Niagara, white; 1 Moore's Early, black; most popular of all apples.

Agents charge $\$ 4.00$

No. 34-10 Pear Trees, extra size, 2 year, 5 to 6 feet, Keiffer and Garber, surest money makers for the middle west.

Agents charge $\$ 5.00$ to $\$ 7.00$ 


\section{Compare These Prices With Those You See Elsewhere Read Our Guarantee-Then}

Make out your order and mail it today. There is plenty of time yet for planting if you order Planters trees, because we ship them fresh, straight to you and guarantee everything we send to arrive in good growing condition. You can depend on sturdy, fresh, healthy, well-rooted stock, true-to-name, packed right and delivered right. Our big, broad guarantee makes you absolutely safe. Send your order today and let us prove in your orchard that the Planters Way saves you the most money and insures you the best trees. We take the risk. Money back if you're not well pleased.

\section{APPLES}

Baldwin. Yellow Transparent, Early Harvest, Red June, Duchess. Maiden Blush Wealthy, Northern Spy, Ben Davis. Black Ben, Stayman, Gano, Winesap. M. B. Twig, Arkansas Black, Grimes Golden, Jonathan, David, Golden Sweet and 20 others.

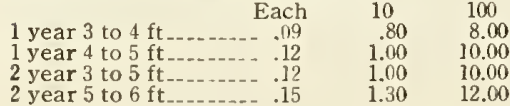

\section{CRAB APPLES}

Florence, Whitney, Transcendent and others. Same prices as apples.

\section{PEACHES}

Belle of Georgia. Elberta, Blood Cling Carmen, Champion. Craw fords Late. Greens boro, Heath Cling, Salway. Triumph, Wonderful, Mayflower. Elberta Cling. Alexander, Crawford's Early, Early Rivers, Mamie Ross, Early Elberta, Late Elberta and $\mathrm{m}$ a $\mathrm{n}$ y others.

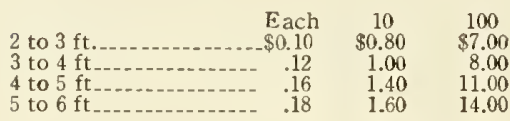

$$
\begin{aligned}
& \text { Early Wonder Peach } \\
& \begin{array}{rrr}
3 \text { to } 4 \mathrm{ft} & \text { Each } & 10 \\
4 \text { to } 5 \mathrm{ft} & &
\end{array}
\end{aligned}
$$

Think of one tree producing a peck of peaches 16 monts after planting-two bushels the second year. That's what one planter re. ports from the astonishing Early Wonder. The marvel of every fruit-grower. Hardy. bears loads of luscious, red peaches every year. Tested and proven from Massachusetts to Texas. Ripens in July when good peaches are scarce. Best early peach for canning and market. You wouldn't take $\$ 5.00$ a tree when they start to bear.

\section{PEARS}

Anjou, Bartlett, Seckle, Duchess, Clapp"s Favorite and other leading sorts.

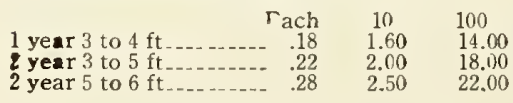

\section{KEIFFER AND GARBER PEAR}

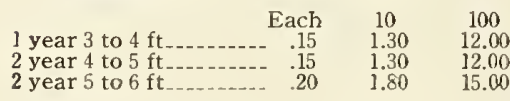

\section{DWARF PEARS}

Duchess. Seckle, Bartlett-the best three.

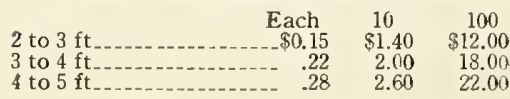

\section{PLUMS}

Burbank, Goild, Red June, Wild Goose Abundance, Satsuma, Wickson, Milton, and other standard sorts.

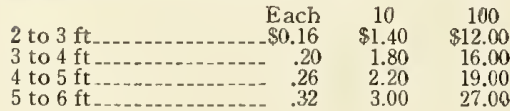

\section{APRICOTS}

Moorpark, Royal, Superb and others

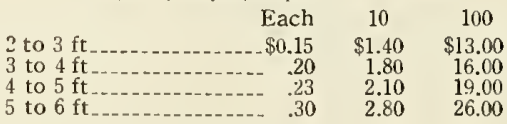

\section{CHERRIES}

Early Richmond, Montmorency, Wragg. Royal Duke, English Morello and other good \begin{tabular}{lrrr} 
& Each & \multicolumn{1}{c}{10} & 100 \\
1 year 3 to $4 \mathrm{ft}$ & $\$$ & $\$ 2.00$ & $\$ 18.00$ \\
1 year 4 to $5 \mathrm{ft}$ & $\$ 0.22$ & $\$ 2.00$ & 24.00
\end{tabular} 2 year 4 to $5 \mathrm{ft}=-\begin{array}{rrr}-30 & 2.80 & 26.00\end{array}$

\section{COMPASS CHERRY-PLUM}

Hardy from Texas to Dakota. Large bright red, sweet and juicy. A marvel in early bearing. Produces fruit next year after setting. Should be in every orchard.

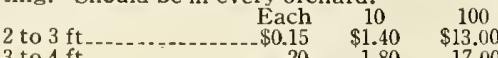

3 to $4 \mathrm{ft}$

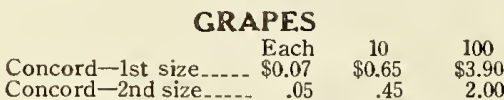
Moores Early, Worden, Niagara, Agawam, Catawba, Diamond and other good varieties at the following prices: Each $10 \quad 100$

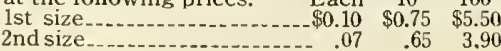

\section{BLACKBERRIES}

Early Harvest, Kenoyer; Mercereau.Ward, Blowers, Snyder and other leading varieties. $\begin{array}{lcccc}\text { Strong healthy } & \text { Each } & 10 & 100 & 1000 \\ \text { plants } & \$ 0.08 & \$ 0.50 & \$ 2.40 & \$ 17.50\end{array}$

\section{DEWBERRIES}

$\begin{array}{rlrr}\text { Lach } & 10 & 100 & 1000 \\ \text { Lucretia and Austin_\$0.05 } & \$ 0.25 & \$ 1.50 & \$ 15.00\end{array}$

\section{RASPBERRIES} $\begin{array}{rccc}\text { Each } & 10 & 100 & 1000 \\ \text { St. Regis (red)_- } \$ 0.08 & \$ 0.50 & \$ 2.20 & \$ 18.00\end{array}$ Cuthbert (red), Kansas (black), Cumberand (black) Plum Farmer (black), Cardinal (purple), Gregg, and other choice varieties. Strong healthy Each $10 \quad 100 \quad 1000$ plants _..._. $\$ 0.05 \quad \$ 0.40 \quad \$ 1.90 \quad \$ 14.00$

\section{GOOSEBERRIES}

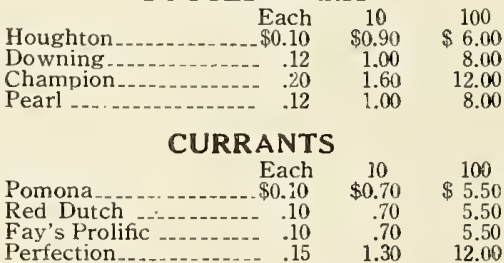

\section{GARDEN ROOTS}

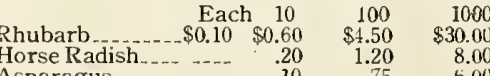

\section{Forest Tree Seedlings}

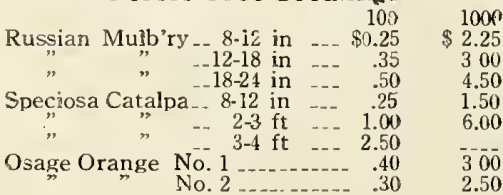

ORNAMENTAL TREES

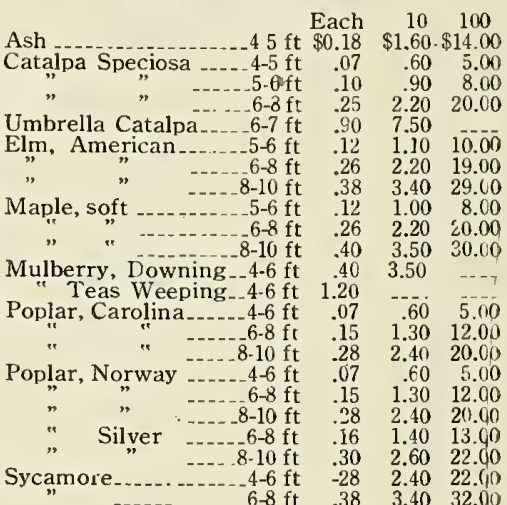

ORNAMENTAL SHRUBS

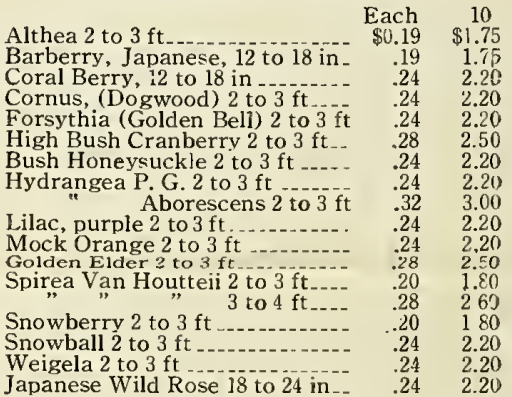

HEDGE PLANTS

Japanese Barberry 12 to $18 \quad \ldots \quad \begin{array}{ccr}10 & 100\end{array}$ Privett, California 12 to 18 in --- $\quad .40 \quad 3.00$ Spirea Van Houtteii i2 to 18 in - . $\quad 1.80 \quad 12.00$ VINES

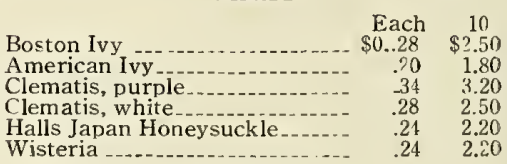

\section{ROSES}

Strong, 2-year-old, hardy, field grown plants, 12 to 18 inch tops. The kind that grow and bloom the first year.

Each 10

Large assortment

10

\section{CLIMBING ROSES}

Each 10

$\begin{array}{lrr}\text { Crimson Rambler } 2 \text { year } \ldots \ldots .- & \$ 0.25 & \$ 2.00 \\ \text { Dorothy Perkins } & .25 & 2.00\end{array}$ White Rambler " -

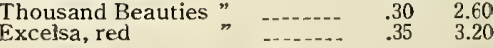

\section{PEONIES}

$\begin{array}{lrc} & \text { Fach } & 10 \\ \text { Assorted varieties............. } & \$ 0.24 & \$ 2.20\end{array}$

\section{NUT TREES} $\begin{array}{lrr}\text { Am. Sweet Chestnut } 3 \text { to } 5 \mathrm{ft}--- & \$ 0.32 & \$ 3.00 \\ \text { Walnut, black } 3 \text { to } 4 \mathrm{ft} & .20 & 1.60\end{array}$ 


\section{Special Home Orchard Collections}

\section{Wonderful Bargains for April Planters}

No. 5-Peach Collection. 10 Select, 4 to 5 $\mathrm{ft}$. trees, 3 Elberta, 1 Belle of Georgia, 2 Champion, 1 Crawford's Late, 2 Carmen, 1 Heath pling. Sold by agents for $\$ 3 . \ldots . . . \$ 1.10$

No. 7-20 Peach Trees. 3 to $4 \mathrm{ft}$. early to late assortment, selected for your locality. Sold by agents for $\$ 5$.

No. 10-10 Pear Trees. 3 to $5 \mathrm{ft}$. Keiffer and $\mathrm{Garber}$, the surest money makers for the middle west. Agents charge $\$ 3$ to $\$ 5$ _ $\$ 1.00$

No. 13-10 Cherries. 1 yr. 3 to $5 \mathrm{ft}$. nicely branched. Early Richmond and Montmorency, the two leading varieties. Agents' 1916 price $\$ 7.00$

No. 14-Grape Coltection. 10 Choice $1 \mathrm{yr}$. vines, 1 Catawba, red; 3 Concord, black; $2 \mathrm{Ni}$ agara, white; 1 Moore's Early, black; 3 Wor-
den, purple. Agents get $\$ 2 . .75$

No. 15-25 Concord Grape Vines. Black. Most widely planted. Agents get $\$ 1.50 \quad \mathbf{. 5 0}$

No. 17 - Berry Collection. 50 Choice plants, 10 Kansas raspberry, black; $10 \mathrm{St}$. Regis raspberry, red; 10 Mercereau blackberry, 10 Blowers blackberry, 10 Houghton Gooseberry. Sold by agents for $\$ 7$... $\$ 2.20$

No. 20-45 Garden Roots. 10 Mammoth Rhubarb, 10 Horseradish, new variety; 25 se-
lect Asparagus. Agents get $\$ 3.25$..- $\$ \mathbf{1} .20$
Read these bargains carefully. Here are the choicest varieties sturdy, vigorous, healthy well rooted stock - made up into special collections for the home orchard. The quality will delight you. The prices speak for themselves. You can select a complete home orchard from these collections at one-third agents' prices. Read our guarantee then take advantage of these remarkable offers.

No. 37-10 Pear Trees. 2 yr. 5 to $7 \mathrm{ft}$. extra size, Keiffer and Garber, surest bearers, most resistant to blight. Biggest offer ever made on big. fine rooted pear trees .......

No. 38-10 Compass Cherry Plum. 3 to $4 \mathrm{ft}$. The fruit that bears when all others fail. Frostproof. Big, bright red, sweet and juicy. Unsurpassed for canning, bears second year. Succeeds everywhere.

No. 41-100 Blackberry Plants. 50 Early Harvest, early; 25 Kenoyer, medium; 25 Mercereau late. Root cutting plants, not suckers..- $\$ 1.95$
No. 31-300 Blackberries. Early Harvest the surest and most productive berry. Succe eds everywhere. Choice root cutting plants, medium size. The greatest bargain Order quick. .....

No. 39-10 lmproved Elberta. Huge golden yellow free stone, one-half larger than old Elberta, firmer, finer flavored, bears younger, yields enormous crops. Well rooted, 1 to 2 foot trees.

No. 44-50 Elberta Peach, 1 to $2 \mathrm{ft}$. The most widely planted peach, the greatest profit maker, good, well rooted trees that will grow and bear quick. .......... \$2.00

No. 47-Pear Collection. 10 select 5 to 6 ft. trees, Keiffer, Garber, Bartlett and Clapps Favorite. Agents get $\$ 6$....... \$1.90

No. 48-Apricot Collection. 10 select 3 to $5 \mathrm{ft}$. trees, Moorpark, Royal and Superb, the choicest and most dependable varieties. Agents get $\$ 5$. Exceptional bargain at $\$ 1.95$

No. 49 - Peach Collection. 20 choice trees, Belle of Georgia, Champion, Elberta, Stump, Blood Cling, Alton and other choice varieties; vigorous, big rooted, 1 to 2 foot
No. 50-20 Apple Trees. 2 yr. 4 to $5 \mathrm{ft}$. 1 yr. tops, extra fine grade. Stayman, Black Ben and Winesap, three of the most successful apples.

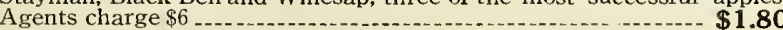

No. 51-Apple Collecirion. 10 select 2 yr. 5 to 7 foot trees, Delicious, Stayman, Black Ben and Winesap. Agents ask $\$ 5.00$. Our best apple bargain, at....

\section{Read What These Planters Say}

Best in Five-The trees arrived in good shape. I had to open the box to show the people the trees before I left town. They all thought I would be stung ordering trees by mail order, but they all left and said I had as good trees as ever shipped in. My neighbors came to see them and they were all satisfied. I have ordered from five other nurseries, but yours is doing better than any of the others. I am proud of the way they are growing. - P. I. Nelson, Kansas.

Sure Saved Commission-I was well pleased with the trees received from you. The trees and grape vines were of good quality and the prices for same were reasonable. The agent's commission was certainly cut out.-W. N. Oles, Kansas.
Trees Well Packed-Trees received in fine condition. The are the best value for the money in fruit trees ever received, also were well packed. Will recommend your nursery to my friends. - F. W. Pearson, Texas.

Better Roots-Your trees arrived in good shape, every one looked as if it would grow. I am much pleased with them as they have better roots than any we have got from local nurseries. Will speak a good word for you at any time.-F. F. Ellerbeck, Kansas.

Saves Over Half-The trees I received of you are just fine. They are all growing-everyone of them. Will recommend you to anyone wanting trees, and the cost is hardly half what agents charge for inferior stock. $-\mathrm{H}$. G. Loveland, Kansas.

\section{Our Positive Guarantee}

We guarantee all trees and plants absolutely true to name. We guarantee safe delivery, quality and satisfaction. We take all the risk of pleasing you. If you don't find the stock exactly as described-if you don't find it equal to or better than trees costing from two to five times as much, you may have your money back, including all transportation charges. You are to be the judge. Certificate of health with each shipment.

Terms. Cash with order. If more convenient, onefourth cash may be sent with order, balance to be paid on arrival of shipment.

Prices. We allow the 100 rate on 50 or more trees of a kind, as 50 apple or peach, not less than 10 of a variety. Less than 10 of a variety take the each rate. In buying small fruits, 500 of one variety take the 1000 rate.

Free Packing. We make no extra charge for packing, drayage, etc.

Freight or Express. With the exception of strawberries which are sent prepaid, all prices are f. o. b. Winfield, customer paying freight or express. We have good service in all directions. Trees and plants take special freight or express rates. It will be a small item compared to the saving you make. Orders up to 35 pounds will go by express as cheap as freight. 3 to 5 foot trees average $\frac{1}{2}$ to 1 pound each; 5 to 6 foot trees, 2 to 3 pounds each, packed for shipment.

Our Reliability. Our announcements are appearing in many of the leading farm and fruit papers, who puklish only guaranteed advertisements. If you have any doubt about getting a square deal from the Planters Nursery, write to any of these publishers. or the Cowley County National Bank, Winfield, Kansas. 
Keiffer Pear-the Money Maker

Plant pears that resist blight. That's why you want Keiffer, the most widely planted and dependable variety. Fruit is extra large, rich golden yellow with red cheek, juicy, brittle, good quality, fine aroma. Bears very young, yields enormous crops every year. Tree is stron and vigorous, easy to grow, successful where other varieties have died from drouth and blight. Fine shipper and excellent keeper, the surest and best variety for the middle west. A good Keiffer orchard is alway a money maker. People would buy ten times as many pears if they could get them. Now is the time to plant. Prices lower than ever before. You will never see finer grown trees than these; smooth bodies, splendid roots, perfect in every respect. You have never had a chance like this to start a pear orchard.

$$
\begin{array}{ccc}
2 \text { yr. 5 to 6 feet } 20 \mathrm{c} & 10 & 100 \\
\$ 1.80 & \$ 15.00
\end{array}
$$

The Fanous Delicious Apple

A wonderful apple. The favorite for quality; a brilliant red streaked with yellow. The flesh is fine grained, crisp and juicy, and its flavor is without an equal. It's one of the hardiest varieties, vigorous and productive and thrives in all apple sections. No matter how many other apples are on the market, Delicious always brings a fancy price. Here's your chance to get genuine Delicious trees at the lowest prices ever offered on this grand apple. Order quick before the supply is gone.

$$
2 \text { yr. } 5 \text { to } 6 \text { feet.... Each } 15 \mathrm{c} \quad \begin{array}{lll}
10 & 100 \\
\$ 10 & \$ 12.00
\end{array}
$$

Stayman Winesap

You Can't Find a Better Apple

Many consider it the greatest of apples. Begins bearing young. Yields big crops every year. Great drouth resister. Thrives on thin soil where many apples fail. Successful wherever apples grow. It's bigger and better than Winesap. Color yellow covered with dark red streaks. Flesh crisp, firm, rich and delightful. Fine for eating all winter long. Splendid keeper. Brings top prices on every market. Be sure to in clude Stayman on your order at these money-saving prices:

Each $\quad 10 \quad 100$

1 vear, 4 to 5 feet $12 \mathrm{c} \quad \$ 1.00 \quad \$ 10.00$ 2 vear, 5 to $f$ feet...15e $1.30 \quad 12.00$

\section{Special Blackberry Offer}

Don't plant cheap sucker plants dug up from run down patches. They bear poor, hard cored fruit, not worth fooling with. Get genuine root cutting plants if you want b i g crops of fine berries. Here is our big offer on Early Harvest, the earliest and most dependable variety. We want you to prove for yourself how much better our root cutting plants grow and bear. Only a limited number reserved for this offer. Order quick.

$\begin{array}{rrr}25 & 100 & 500 \\ \text { Prices_... _. . 50 } & \$ 1.65 & \$ 6.25\end{array}$

\section{Improved Elberta America's Greatest Peach}

Elberta has made more money for peach growers than all other varieties put together. Here's a bigger and better Elberta, improved in size, color, flavor and quality. Bears second to third year, yields enormous crops. Its rich golden yellow color, huge size, firm meat, and fine flavor, brings the highest prices on every market. Best shipper, the favorite for canning. Ripens here Aug. 10-20. Here is a special demonstration offer that you can't afford to pass. It's our best bargain. These are sturdy little trees with wonderful roots.

$\begin{array}{lll}\text { Each } & 10 & 100\end{array}$

1 to 2 feet_..... $8 \mathrm{c} \quad 60 \mathrm{c} \quad \$ 4.00$

\section{(i) A April Bargain Bulletin

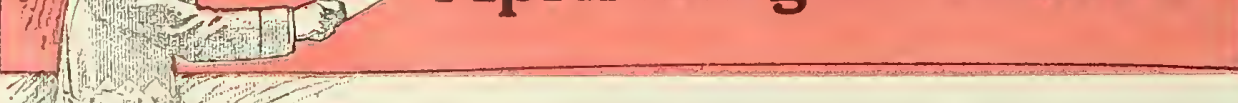 \\ Brings you the greatest bargains ever offered in fruit trees, small fruits, ornamental trees and plants- everything for the orchard and fruit garden.}

April is the biggest and best planting month of the year. Now is the time to plant that new orchard, fill in the old one, get your trees and berries for the fruit garden, and beautify the home with trees and shrubs.

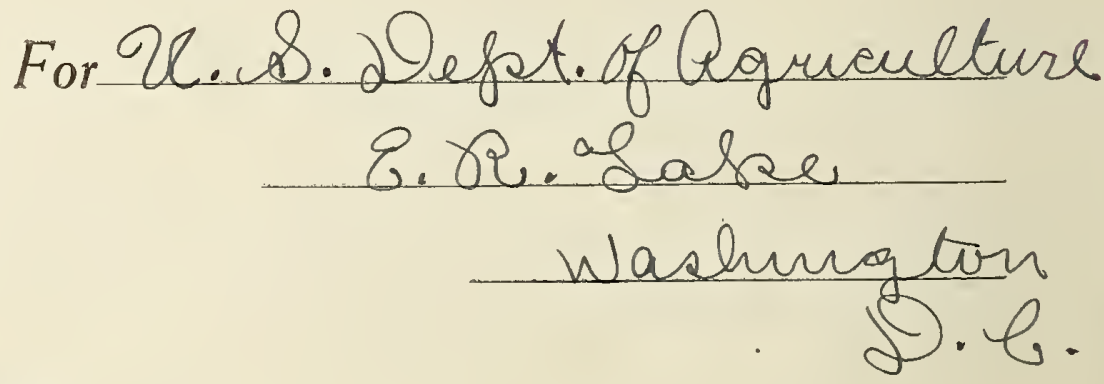

Postmaster-If this IMPORTANT MATTER cannot be delivered, please notify The Planters Nursery, Winfield, Kansas, giving reason, and postage will be sent for forwarding or return Use form 3540. See P. L. \& R. Sec. 675 and 676 . 